\title{
LIV. On the stones said to have fallen at ensisheim, in the neighbourhood of agen, and at other places
}

\section{De Dree}

To cite this article: M. De Dree (1803) LIV. On the stones said to have fallen at ensisheim, in the neighbourhood of agen, and at other places, Philosophical Magazine Series 1, 16:64, 289-298, DOI: $10.1080 / 14786440308676348$

To link to this article: http://dx.doi.org/10.1080/14786440308676348

曲 Published online: 18 May 2009.

Submit your article to this journal

Џ Article views: 2

Q View related articles $\square$ 


\section{$\left[\begin{array}{ll}289 & 3\end{array}\right.$}

LIV. On the Stones said to have fallen at Ensisheim, in the Neighbourhood of Agen, and at other Places. From the Memoir of M. DE DREE*.

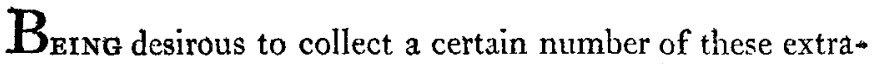
ordinary facts, that I might compare them with each other, I sought for and obtained some correct ideas respecting two masses of this kind; one of which fell near Ensisheim, and the other in the environs of Agen. These stones, indeed, have been already mentioned; but as the latter was neither analysed nor described mineralogically-as the circumstances of the fall of the former are imperfectly known-and as, at the period at which $\mathrm{Mr}$. Barthold professor of the central school of the Upper Rhine described and analysed it, he could not search for certain distinguishing characters of this kind of stones, which were not then known-I thought it might be of importance to give an account of them here, in order to remove all uncertainty respecting the nature of these bodies.

\section{Stone of Ensisheim.}

The stone known under this name, which fell at Ensisheim in Alsace, made a great noise, especially about the end of the fifteenth century, and is mentioned in several works. Mr. Butenschoen, professor of history in the central school of Colmar, gave some account of it, which was inserted in the Decade Philosophique; and to the kindness of that 'gentleman I am indebted for the following extracts from the chronicles of the time.

Literal Translation of a German Notice resperting the Stone of Ensisheim, which was formerly preserved along with that Stone in the Parish Church of the Place.

"Or.Wednesday, Nov. 7. the night before St. Martin's day, in the year of our Lord 1492, a singular miracle happened : for between the hours of eleven and twelve a loud clap of thunder took place, with a long-continued noise, which was heard at a great distance; and a stone fell from the heavens in the Ban of Ensisheim which weighed 260 pounds; and the noise was much louder in other places than here. A child then saw it strike on a field situated on the upper Ban, towards the Rhine, and the In, near the

* See the last Number of the Phil. Mag.

Vol. XVI. No. 64. September 1803,
$\mathrm{T}$

canton 
canton of Gisgane, which was sown with wheat. It did no hurt, except that it made a hole there. It was afterwards transported thence; and a great many fragments were detached from it, which the land-vogt forbade. It was then deposited in the church, with intention of suspending it as a miracle; and a great many people came hither to see this stone, respecting which there were singular discourses. But the learned said they did not know what it was, for it was something supernatural that so large a stone should fall from the atmosphere; but that it was a miracle of God : because, before that time, nothing of the kind had ever been heard of, seen, or described. When this stone was found, it had entered the earth to a depth equal to the height of a man. What every body asserted was, that it had been the will of God that it should be found. And the noise of it was heard at Lucerne, at Villing, and many other places, so loud, that it was thought the houses were all overturned. And when king Maximilian was here, the Monday after St. Catharine's day of the same year, his royal excellency caused the stone which had fallen to be carried to the castle; and after conversing a long time with his lords, he said the people of Ensisheim should take it : and he gave orders that it should be suspended in the church, and that no person should be permitted to take any part of it. His excellency, however, took two fragments; one of which he kept, and the other he sent to duke Sigismund of Austria. The people talked a great deal of this stone, which was suspended in the choir, where it still is, and many came to see it."-Arithenicus in Chronico Hirsaugiensi, in Vitâ Blavii Albatis xL. ad Annum 1492. Edit.M.S. Galli, 1690, Vol. II. p. 551.

"The same year (1492), on the 7 th day of November, a stone, called a thunder-stone, of a prodigious size (for we have it from eye-witnesses that it weighed 255 pounds), fell from the heavens in the village of Suntgaw, near the town of Ensisheim, not far from Bale, a city of Germany. Its fall was so violent that it broke into two pieces. The largest is still to be seen at the door of the church of Ensisheim, suspended by an iron chain, as a proof of the truth of the fact which we announce, and to preserve the remembrance of it." -Paulus Lang, in Chronico Cirizense, in Vol. III. Scriptor. Rer. Germ. Histor. p. 1264.

" On the 7th of the ides of November, in the year of our Lord 1492, there arose a storm, during which the heavens appeared to be on fire. While the thunder roared, a stone of a prodigious size fell from the heavens, with a horrible crash, near the town of Ensisheim, on the lands belonging 
to the emperor Frederick. Its form was that of a delta, with a triangular point. It is still shown at Ensisheim as a wonderful phænomenon."-Joh. Linturii Appendix ad Fasciculum Temporum Werneri Rollewinck, in Vol.I. Scriptor. Rer. Germ. Histor. p. 580.

The sathe year (1492), after the festival of St.Martin, a stone weighing 300 pounds and more, hard, and of different colours, fell in Alsace, with a great noise, from a brilliant and flaming cloud. The rest of the horizon exhibited no clouds. At the same moment, the hearens being still serene, a large red cross was observed around the moon.

In a rescript of king Maximilian, dated Augsbourg, Nov. 12, 1503, that sovereign mentions this stone, which he says fell near him while at the head of his army; and he gives it as a presage of the victory which he had gained over the crown of France*.

Brant also has made this stone the subject of some poems $\uparrow$.

One of the fragments of this stone was suspended and preserved in the church of Ensisheim till a few years back, when it was conveyed to the library.of Colmar, and there deposited. It weighs about 150 pounds at least, notwithstanding the specimens which have been detached from it ; and professor Butenschoen says that this stone is beyond all doubt that spoken of in the before-mentioned chronicles.

M. Felix Desportes, præfect of the department of the Upper Rhine, having permitted several fragments to be detached from this mass, in order to be sent to me, I am indebted to that zealous protector of the sciences, and to professor Butenschoen, for the advantage of being able to give a comparative description of its characters, and for an analysis of it, which Vauquelin undertook to make.

"The different specimens of this stone which I received did not exhibit that continued black vitrified crust observed on the stone of Sales, and other stones of the same kind; but I discovered this crust in the cavities which had been sheltered from the shock and from friction; and these remains are sufficient evidences to attest that this crust had existed. It exhibits the puffed-up appearance of vitrification : the colour is only rather brown than black; which arises cither from the effect of time, or from the greater quantity

- Rescriptum Maximiliani regis de cruciata, \&c. die $12 \mathrm{Nov} .1503$, in vol. Rer. Germ. nono, de pace publica, autore J P. Datt. Ulm, x698, P. 214 .

+ De fulgetro immani jam nuper, anno 1492, prope Basileam, \&c. In varuis Sebastiani Brant carminibus. Basilez, 1498 , 4 to. 
of iron diffused throughout the mass, as will be seen hereafter.

As this stone has a great resemblance to that of Sales, I shall for the sake of brevity give only a comparative description of them.

In this stone, as well as in that of Sales, there are found malleable iron, containing nickel disseminated throughout it in grains; lamellated and whitish sulphuret of iron in the form of lumps and grains; gray sulphuret of iron less sulphurated; in thin scaly strata, which line a multitude of small fissures which traverse the stone in every direction : but it is observed thet the white pyrites in it form larger lumps, and that the gray pyrites is more abundant than in that of Sales.

Small anygdaloid globules might perhaps be seen in it; but as they have a more metallic fracture than those of the stone of Sales, as they are almost confounded in regard to appearance with the mass, they do not deserve particular: attention. Its interior colour is darker and bluer than that of Sales, and its fracture is somewhat changeable in its colour, in consequence of the metallic splendour of small fissures, which give it a different appearance by the magnifying glass; and on the transverse branches of these fissures it is observed, that this texture and the constituent elements are the same in both, except in regard to the grain, which is finer, and the tissue, which is more compact, than in that of Ensisheim.

On carefully examining the differences which I observed between this stone and that of Sales, and which distinguish it also from the stones of Agen and of Benares, and from others of the same kind about to be mentioned, it will be seen that they do not relate to the constituent elements, but only to their proportions; it is therefore impossible not to discover that this mineral mass is of the same nature ss that of Sales and athers of the like kind. This is confinued by the following note, communicated to me by Vauquetin:

"This stone has a perfect resemblance in the number, nature, and quantity of its constituent principles, to at the stones said to have fallen from the clouds which have hitherto been subjeeted to chemical analysis. .

"It is certainly compoșcd of silex, magnesia, iron, nickel, sulphur, and a small quantity of lime.

"I have ascertained, by particular trials, the presence of miphur and nickel in the grains of malleable iron, and in the pyrites, but in different proportions. This stope there- 
fore resembles, in every point, all those which have fallen from the atmosphere."

\section{Stones of Agen.}

The stones known under the name of the stones of Agen have been mentioned in the Billiothèque Britannique * Their fall has been confirmed by numerous testimonies and authentic documents, inserted by M. Bertholon in the Jotrnal des Sciences utilest.

According to the above accounts, these stones fell on the 24th of July 1790 , between nine and ten in the evening, in the communes of Juliac, Creon, and others adjacent, between Roquefort in the department of Landes, Mezin in the department of Lot and Garonne, and Eause in the department of Gerz, after the apparition of a large fire-ball which passed through the air, accompanied with a loud report.

They fell at different distances; some gently, and others with rapidity and a hissing noise.

They buried themselves more or less in the earth : several had fissures in them.

Their weight in general was between a quarter of a pound and two pounds : some of them, however, are said to have weighed from twenty to twenty-five pounds; and Mr. St. Amand saw in the museum of Bourdeaux one of these fragments about fifteen inches in length, taken from a stone which, as said in the accompanying note, crushed a cottage, made a conical hole of about five feet in depth, and killed a farmer and some cattle, at the time of the explosion of July 24, 1790, near Roquefort in Landes.

There is no stone in the place where they fell which has any resemblance to them.

Mr. Darcet was so kind as to transmit to me a fragment of one of these stones, which fell near Barbotan, a place situated within the boundaries above traced out. It was that subjected to analysis by Vauquelin.

This stone has so great a resemblance to that of Sales, even in the most minute particulars, that the mineralogical description would be the same, and therefore I refer to the latter. It has the same vitrified crust; the same substances included, and nearly in the same proportions ; the same texture, hardness, and aspect ; the same chemical characters.

The analysis made of it by Vauquelin gave him the same chemical substances as the other stones, and in proportions nearly the same.

* No.154. p. 85.
+ No. 23. and 24. 1790.

3. Notice 
3. Notice respecting a Mass of Iron which fell in the Mogul Territories. Communicated by Mr. GREviLLE to the Royal Society of London.

All the masses of iron of unknown origin, such as those found in Siberia, America, \&c. contain nickel, and have besides characters analogous to those of the stones which have fallen from the clouds. These circumstances induced $\mathrm{Mr}$. Howard and Count de Bournon to conclude that these substances might have had the same origin. The following fact tends to confirm this opinion. Mr. Greville, who communicated it to the Royal Society, extracted it verbatim from the Memoirs of Jehangire emperor of the Moguls, written in Persian by himself, and translated by colonel William Kirkpatrick.

" $A . H .1030$, or the 16 th of the reign. The following is among the extraordinary occurrences of the period.

"Early on the 30th of Furverdeen of the present year*, and in the eastern quarter (of the heavens), there arose in one of the villages of the purgunnaht of Jalindher such a great and tremendous noise as had nearly, by its dreadful nature, deprived the inhabitants of the place of their senses. During this noise a luminous body (was observed) to fall from above on the earth, suggesting to the beholders the idea that the firmament was raining fire. In a short time, the noise having subsided, and the inhabitants having recovered from their alarm, a courier was dispatched (by them) to Mahomed Syeed, the aumil $\ddagger$ of the aforesaid purgunnah, to advertise him of this event. The aumil instantly inounting (his horse) proceeded to the spot (where the luminous body had fallen). Here he perceived the earth, to the extent of ten or twelve guz $\S$ in length and breadth, to be burnt to such a degree, that not the least trace of verdure, or a blade of grass, remained; nor had the heat (which had been communicated to it) yet subsided entirely.

"Mahomed Syeed hereupon directed the aforesaid space of ground to be dug up; when the deeper it was dug the greater was the heat found to be. At length a lump of iron made its

The first of Furverdeen of this year (A.H. ro3o) corresponded with Saturday the 27th of Rubbi ul Aklir; consequently the zoth of Furverdeen fell on the 2 oth of Jummad ul Ouwul, or A.D. 1620.

t A purgunnah is a territorial division of arbitrary extent. The pur. ganuah of Jalindher is situated in the Punjaub, and about roo miles south. east of Lahor.

\pm Aumil is a manager or fiscal superintendant of a district.

$\$ \mathrm{~A}$ guz is rather less than a yard.

appearance, 
appearance, the heat of which was so violent that one might have supposed it to have been a furnace. After some time it became cold ; when the aumil conveyed it to his own habitation, from whence he afterwards dispatched it, in a sealed bag, to court.

"Here I had (this substance) weighed in my presence. Its weight was 160 tolahs *. I committed it to a skilful artisan, with orders to make of it a sabre, a knife, and a dagger. The workman (soon) reported that the substance was not malleable, lut shivered into pieces under the hammert.

"Upon this I ordered it to be mixed with other iron. Conformably to my orders three parts of the iron of lightning $\ddagger$ were mixed with one part of common iron; and from the mixture were made two sabres, one knife, and one dagger.

"By the addition of the common iron, the (new) substance acquired a fine temper; the blade (fabricated from it) proving as elastic as the most genuine blade of Ulmanny $\S$ and of the south, and bending like them without leaving any mark of the bend. I had them tried in my presence, and found them cut excellently; as well (indeed) as the best genuine sabres. One of these sabres I named $k a$ tai, or the cutter; and the other, lurk-serisht, or the lightning natured.

"A poet || composed and presented to me, on this occasion, the following tetrastich :

" This earth has attained order and regularity through the emperor Jehangire.

"In his time fell raw iron from lightning:

"That iron was by his word-subduing authority converted into a dagger, a knife, and two sabres.'

"The chronogram of this occurrence is contained in words which signify ' the flame of the imperial lightning,' and give the year (of the Hegira) 1030.

"N.B. The foregoing translation (which is nearly literal) has been made from a manuscript that has been several years in my possession; and which, although without a date, bears marks of having been written at a remote period.

"WILliam KinkPatrick."

* A tolah is ahout 180 grains Troy weight.

+ Literally, "it did not stand beneath the hammer, but fell to pieces."

+ This expression is equivalent to our term tbunder-bolt.

$\$$ The name of the place here designed is doubttul.

If The poet is named in the original, but the name is not perfectly legible. 


\section{Notice respecting the Stones which fell lately in France.}

In the sitting of the Institute on the gth of May, C.Fourcroy read a letter addressed to $\mathrm{C}$. Vauquelin from the town of Aigle, in the department of Calvados (the ci-devant Normandy), containing a cireumstantial account of the recent fall of a considerable number of stones. The following details are extracted from it :

On April 26th; about one in the afternoon, the sky being almost serene, there was heard a rolling noise like that of thunder. It seemed to proceed from one cloud which was on the horizon, and which the inhrabitants beheld with uneasiness ; when, to their great surptise and terror, explosions like the reports of a cannon, sometimes single and sometimes double, were heard, with a violent hissing : phænomena which struck a terror even into domestic animals, for the cows bellowed, and the poultry fled to a place of shelter. This noise was succeeded by the fall of a great number of storres of different sizes, weighing ten, eleven, and even seventeen pounds. The largest entered the earth to the depth of a foot. Several of them fell in the court-yard of M. Bois-de-la-ville, and one of them very near him. Many curious persons collected some of them, and C. Fourcroy laid before the Institute one of these fragments, which, when compared with the fragment of a stone that fell near VilleFranche, presented to the Institute in the same sitting by C. Pictet, had a great resemblance to it in every point: the same colour, the same texture, the same black crust; in a word, the fragments could not be distinguished from each other but by the size.

C. la Marck then reported that he had received from the department of Calvados several letters, making mention of a globe of fire which had been seen to pass, proceeding in a direction from west to east, with great velocity, on the same day and at the same hour at which the event alluded to took place. It was added, that this meteor had been seen at sea before it reached the continent.

If any doubts remain to our readers on the certainty of the real fall of those foreign bodies of which we have frequently given an account, we request them to peruse a work which has lately appeared under the title of Lithologie Atmosphérique. M. Izarn, the author, who is professor of phulosophy, gives in this work a complete treatise on phænomena of this kind. It is divided into three sections. The first con- 
tains a collection of the facts and opinions published in France since the year 1700 on thunder-stones, thunder, stones fallen from the heavens, \&c. In the second is found a critical examination of the systems hitherto formed on this subject, both in regard to the reality of the fall of stones from the atmosphere, and on their origin and formation. It results from it that the phænomenon of the fall of solid bodies on the earth is, according to every appearance, as old as the world; and that the certainty of the fact is now so well proved, that it can be denied only by those who admit nothing as certain. The third section contains an essay towards a theory on the formation of stony and metallic bodies in the atmosphere. At the end, the author gives a sort of recapitulation of his whole work in the following Tables :-1st, Of the principal opinions entertained in regard to the solid substances which have fallen from the clouds. 2dly, Of the different periods of the fall of these substances on the earth.

Table of the principal Opinions entertained in regard to the solid Substances which have fallen from the Clouds.

Philosophers who have considered them as productions thrown on the earth by volcanoes or hurricanes:

$\begin{array}{ll}\text { Freret, } & \text { Barthold, } \\ \text { Gassendi, } & \text { G. A. Deluc, } \\ \text { Muschembroek, } & \text { Delalande. }\end{array}$

As mineral substances fused by lightning on the spots where found:

$\begin{array}{ll}\text { Lemery, } & \text { Stahl, } \\ \text { The Academicians, } & \text { Gronberg, } \\ \text { Agricola, } & \text { Patrin. }\end{array}$

As concretions in the atmosphere :

Descartes,

Lesser,

Goyons-d'Arzas,
Sir William Hamilton,

Edward King,

Eusebius Salverte.

As masses foreign to our planet:

Chladni, Poisson, Biot, The Bibliothèque Britannique. 


\section{[ 298 ]}

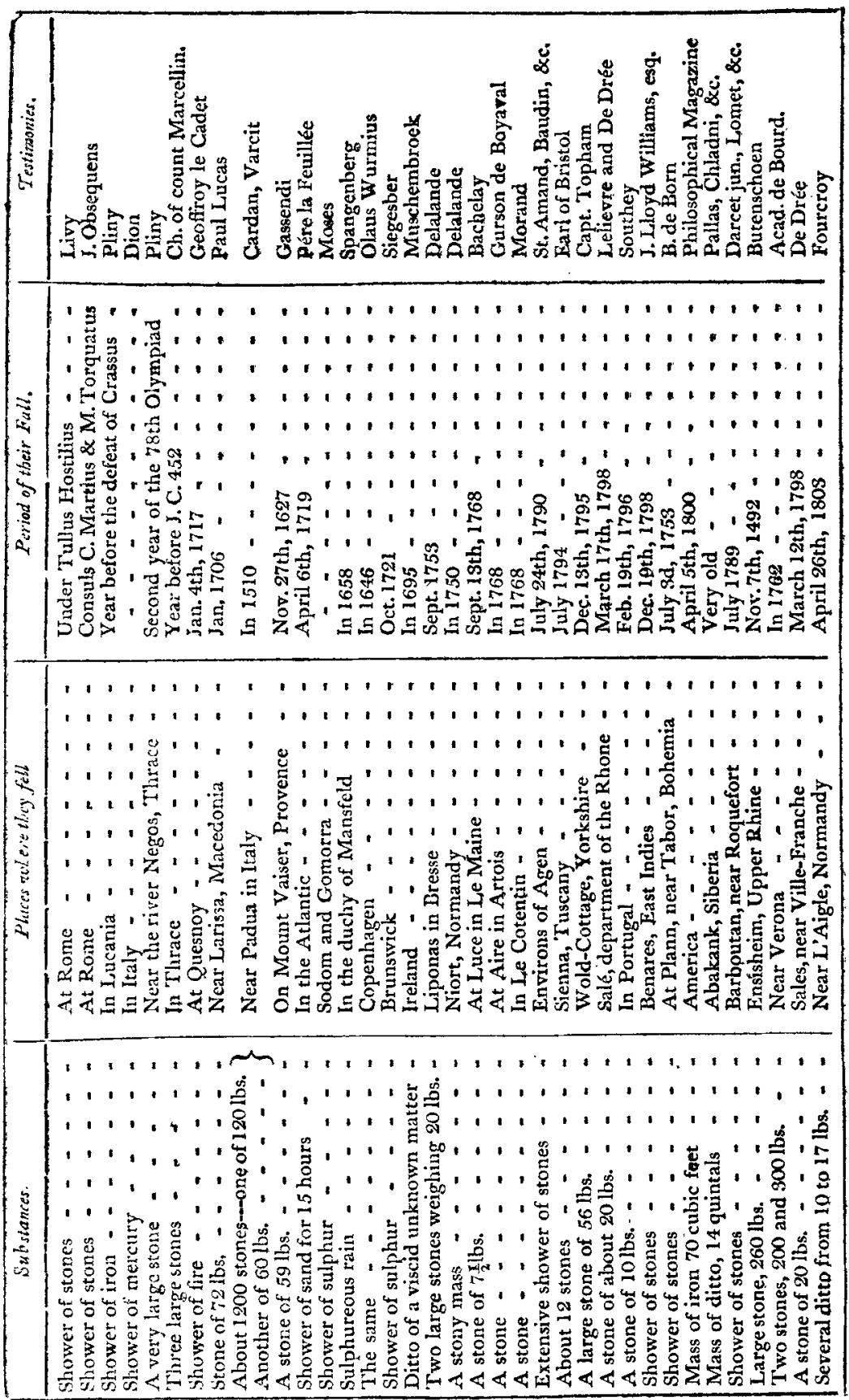

